\title{
A STUDY OF HIV-1 GENETIC DIVERSITY IN THE CZECH REPUBLIC: 1986-2007
}

\author{
Marek Linka ${ }^{1}$, Marie Brůčková ${ }^{1}$, Marek Malý' ${ }^{1}$, Jana Vandasová ${ }^{1}$, Marie Staňkováe, Milan Reiniš ${ }^{3}$ \\ ${ }^{1}$ National Reference Laboratory on AIDS, National Institute of Public Health, Šrobárova 48, 10042 Prague 10, Czech Republic \\ ${ }^{2}$ AIDS Centre, Bulovka University Hospital, Budínova 2, 18081 Prague 8, Czech Republic \\ ${ }^{3}$ Institute of Molecular Genetics, Academy of Sciences of the Czech Republic, Vídeňská 1083, 14220 Prague 4, Czech Republic
}

\section{SUMMARY}

Background: The global HIVIAIDS epidemic consists of a number of regional epidemics caused by different HIV-1 subtypes prevailing in different regions.

Objectives: To study changes in genetic diversity of HIV-1 strains isolated in the Czech Republic (CR) over a more than twenty-year period (1986-2007).

Study Design: HIV-1 strains isolated in CR from 1986 to 2007 were subtyped by pol gene sequencing followed by phylogenetic analysis. The role of HIV-1 subtyping in molecular epidemiology was considered.

Results: A wide range of HIV-1 subtypes were found, with subtype B, into which $76.6 \%$ of $534 \mathrm{HIV}-1$ isolates were classified, being predominant during the whole study period. An increasing number of non-B subtypes A1, C, D, F1, G and some recombinant forms (CRF 01_AE, CRF 02_AG and CRF 06 cpx) were identified after 1990.

Conclusions: The absolute predominance of subtype B among HIV-1 strains in the Czech Republic ended in 1991 when different non-B subtypes had been introduced into the country. The East-West migration is responsible for the introduction of HIV-1 subtypes prevalent in Eastern European and some Asian countries. Genetic analysis of HIV-1 isolates from a given region can be helpful in tracing the course of the HIVIAIDS epidemic.

Key words: HIV-1 subtyping; non-B subtypes; migration; molecular epidemiology.

Address for correspondence: Mgr. Marek Linka, National Reference Laboratory on AIDS, National Institute of Public Health, Šrobárova 48, 10042 Prague 10, Czech Republic. E-mail: mlinka@szu.cz

\section{INTRODUCTION}

The extreme genetic variability is one of the main characteristics of HIV (1). The global HIV/AIDS epidemic consists of a number of regional epidemics caused by different HIV-1 variants (subtypes, clades). In Eastern Europe where the explosive HIV/AIDS epidemic is currently in progress the HIV-1 non-B subtypes are identified as the main causative agents (2-5). The recent East - West population migration waves have faciliated the transmission of non-B subtypes typically prevalent in the Eastern European region to other European countries including the Czech Republic. The present study should provide results to ascertain this assumption.

\section{MATERIALS AND METHODS}

\section{Study Population}

The study population consisted of 534 persons (411 males and 123 females) diagnosed as HIV positive between 1986 and 2007 in the Czech Republic.

\section{HIV Transmission Category}

276 persons were infected through homosexual contact, 179 cases were ascribed to heterosexual contact, 35 subjects were
IDUs, 8 infections were transmitted by blood transfusion, 2 patients acquired infection in health care settings in Romania and 2 cases resulted from MTC transmission. In 32 cases, the mode of transmission was not identified.

\section{Specimen Collection}

Plasma samples were obtained from HIV positive persons presenting for routine testing (immunological examination, viral load testing, etc.). The plasma specimens were stored at $-70^{\circ} \mathrm{C}$ until analysed.

\section{HIV-1 RNA Isolation, Reverse Transcription, PCR Amplification and Sequencing}

The procedures were performed using the ViroSeq HIV-1 Genotyping System (Abbott, Wiesbaden, Germany) according to the manufacturer's instructions.

\section{Subtyping}

The pol-encoded nucleotide sequences (nt positions 2253-3554 in HXB2 HIV-1 reference strain) were subtyped using REGA HIV-1 Automated Subtyping Tool, Version 2.0 (6). 


\section{Statistical Analysis}

The analysis of contingency tables was based on generalized Fisher's exact test, evaluation of standardized residuals in the table (7), and on Cochran-Armitage $\chi^{2}$ test for trend in proportions. All statistical tests were performed at a significance level of 0.05. The software package Stata (Stata Corporation, College Station, TX, USA) was used for data evaluation.

\section{RESULTS}

Altogether 782 plasma samples from 534 HIV positive persons in different clinical stages of infection were analyzed by sequencing methods. The sequences can be retrieved from the GeneBank database under accession numbers AY694208-AY694258; AY694260-AY694293; AY694295-AY694383; DQ974837DQ974884; DQ974886-DQ974902; DQ974904-DQ974917; DQ974919-DQ974951; DQ974953-DQ974957; DQ974959; DQ974961-DQ974989; DQ974991-DQ974997; DQ974999DQ975034; DQ975036-DQ975039; DQ975041-DQ975042; DQ975044-DQ975052; DQ975054-DQ975189; EU672513EU672650; EU672652-EU672657; EU672663-EU672704; EU672706-EU672767; EU672769-EU672782; EU672785; EU672788-EU672791. The samples were collected between

Table 1. Proportion of HIV-1 subtype $B$ in the Czech Republic (1986-2007)

\begin{tabular}{|l|c|c|c|}
\hline \multirow{2}{*}{ Calendar period } & \multicolumn{3}{|c|}{ HIV-1 subtype } \\
\cline { 2 - 4 } & B & non-B & Total \\
\hline $1986-1991$ & $19(95.0 \%)$ & $1(5.0 \%)$ & 20 \\
\hline $1992-1995$ & $25(86.2 \%)$ & $4(13.8 \%)$ & 29 \\
\hline $1996-1999$ & $44(78.6 \%)$ & $12(21.4 \%)$ & 56 \\
\hline $2000-2003$ & $67(77.0 \%)$ & $20(23.0 \%)$ & 87 \\
\hline $2004-2007$ & $254(74.3 \%)$ & $88(25.7 \%)$ & 342 \\
\hline Total & $409(76.6 \%)$ & $125(23.4 \%)$ & 534 \\
\hline
\end{tabular}

1986 and 2008. Changes in HIV-1 subtype were not observed in plasma samples collected from individual patients in different stages of infection.

Subtype B was prevalent over the whole study period in all HIV-1 transmission categories since the very beginning.

Non-B subtypes were introduced into the population under study in 1991. Based on test for trend in 5 calendar periods, the proportion of non-B subtypes had been increasing with time ( $\mathrm{p}$ $=0.017$ ). In the last two periods (2000-2003 and 2004-2007), the upward trend is less pronounced (Table 1).

Time distribution of various HIV-1 non-B subtypes is shown in Table 2. The incidence of different non-B subtypes changed significantly in the course of time $(\mathrm{p}<0.001)$. The analysis of adjusted residuals suggests that a statistically significant increase in the proportion of A1 and CRF_01 AE subtypes occurred in the middle of the period under consideration while that of the CRF_02 AG subtype came about in the past several years. A significant cluster of F1 cases was observed in 1996-1999. The changing pattern of the incidence of $C$ subtype resulted in a deep decrease in 2004-2007.

The most often isolated non-B subtypes are A1, CRF 01_AE, and $C$ representing in total $37.6 \%, 24.8 \%$ and $15.2 \%$ of all non-B strains, respectively. In the last period, A1 and CRF 01_AE accounted for more than two-thirds of all non-B subtypes.

Distribution of HIV-1 subtypes by transmission category is shown in Table 3. Although subtype B prevails in all transmission categories, the determined subtype patterns markedly differ between these categories $(\mathrm{p}<0.001)$. The two most frequent transmission categories, namely those of homo/bisexually and heterosexually transmitted infection, differ completely in subtype pattern $(\mathrm{p}<0.001)$.

While a wide range of subtypes were identified in patients with heterosexually transmitted infection, subtype B was found in almost all male patients having sex with men (in $98.9 \%$ of all HIV-1 isolates in that category).

Table 2. HIV-1 non-B subtypes in the Czech Republic (1986-2007)

\begin{tabular}{|c|c|c|c|c|c|c|c|c|c|}
\hline \multirow{2}{*}{$\begin{array}{l}\text { Calendar } \\
\text { period }\end{array}$} & \multicolumn{9}{|c|}{ HIV-1 subtype } \\
\hline & A1 & C & D & F1 & G & $\begin{array}{c}\text { CRF } \\
01 \mathrm{AE}\end{array}$ & $\begin{array}{c}\text { CRF } \\
02 \mathrm{AG}\end{array}$ & $\begin{array}{c}\text { CRF } \\
06 \mathrm{cpx}\end{array}$ & Total \\
\hline 1986-1991 & $\begin{array}{c}0 \\
(0.0 \%)\end{array}$ & $\begin{array}{c}1 \\
(100.0 \%)\end{array}$ & $\begin{array}{c}0 \\
(0.0 \%)\end{array}$ & $\begin{array}{c}0 \\
(0.0 \%)\end{array}$ & $\begin{array}{c}0 \\
(0.0 \%)\end{array}$ & $\begin{array}{c}0 \\
(0.0 \%)\end{array}$ & $\begin{array}{c}0 \\
(0.0 \%)\end{array}$ & $\begin{array}{c}0 \\
(0.0 \%)\end{array}$ & 1 \\
\hline 1992-1995 & $\begin{array}{c}0 \\
(0.0 \%)\end{array}$ & $\begin{array}{c}3 \\
(75.0 \%)\end{array}$ & $\begin{array}{c}0 \\
(0.0 \%)\end{array}$ & $\begin{array}{c}0 \\
(0.0 \%)\end{array}$ & $\begin{array}{c}0 \\
(0.0 \%)\end{array}$ & $\begin{array}{c}1 \\
(25.0 \%)\end{array}$ & $\begin{array}{c}0 \\
(0.0 \%)\end{array}$ & $\begin{array}{c}0 \\
(0.0 \%)\end{array}$ & 4 \\
\hline 1996-1999 & $\begin{array}{c}5 \\
(41.7 \%)\end{array}$ & $\begin{array}{c}1 \\
(8.3 \%)\end{array}$ & $\begin{array}{c}0 \\
(0.0 \%)\end{array}$ & $\begin{array}{c}4 \\
(33.3 \%)\end{array}$ & $\begin{array}{c}1 \\
(8.3 \%)\end{array}$ & $\begin{array}{c}1 \\
(8.3 \%)\end{array}$ & $\begin{array}{c}0 \\
(0.0 \%)\end{array}$ & $\begin{array}{c}0 \\
(0.0 \%)\end{array}$ & 12 \\
\hline 2000-2003 & $\begin{array}{c}4 \\
(20.0 \%)\end{array}$ & $\begin{array}{c}8 \\
(40.0 \%)\end{array}$ & $\begin{array}{c}0 \\
(0.0 \%)\end{array}$ & $\begin{array}{c}0 \\
(0.0 \%)\end{array}$ & $\begin{array}{c}1 \\
(5.0 \%)\end{array}$ & $\begin{array}{c}6 \\
(30.0 \%)\end{array}$ & $\begin{array}{c}1 \\
(5.0 \%)\end{array}$ & $\begin{array}{c}0 \\
(0.0 \%)\end{array}$ & 20 \\
\hline 2004-2007 & $\begin{array}{c}38 \\
(43.2 \%)\end{array}$ & $\begin{array}{c}6 \\
(6.8 \%)\end{array}$ & $\begin{array}{c}2 \\
(2.3 \%)\end{array}$ & $\begin{array}{c}0 \\
(0.0 \%)\end{array}$ & $\begin{array}{c}6 \\
(6.8 \%)\end{array}$ & $\begin{array}{c}23 \\
(26.1 \%)\end{array}$ & $\begin{array}{c}11 \\
(12.5 \%)\end{array}$ & $\begin{array}{c}2 \\
(2.3 \%)\end{array}$ & 88 \\
\hline Total & $\begin{array}{c}47 \\
(37.6 \%)\end{array}$ & $\begin{array}{c}19 \\
(15.2 \%)\end{array}$ & $\begin{array}{c}2 \\
(1.6 \%)\end{array}$ & $\begin{array}{c}4 \\
(3.2 \%)\end{array}$ & $\begin{array}{c}8 \\
(6.4 \%)\end{array}$ & $\begin{array}{c}31 \\
(24.8 \%)\end{array}$ & $\begin{array}{c}12 \\
(9.6 \%)\end{array}$ & $\begin{array}{c}2 \\
(1.6 \%)\end{array}$ & 125 \\
\hline
\end{tabular}


Table 3. Distribution of HIV-1 subtypes by transmission category

\begin{tabular}{|c|c|c|c|c|c|c|c|c|c|c|}
\hline \multirow{2}{*}{$\begin{array}{l}\text { Transmission } \\
\text { category }\end{array}$} & \multicolumn{10}{|c|}{ HIV-1 subtype } \\
\hline & B & A1 & C & D & $F$ & G & $\begin{array}{c}\text { CRF } \\
01 \_A E\end{array}$ & $\begin{array}{c}\text { CRF } \\
02 \_A G\end{array}$ & $\begin{array}{c}\text { CRF } \\
06 \_c p x\end{array}$ & Total \\
\hline $\begin{array}{l}\text { Homosexual/ } \\
\text { bisexual }\end{array}$ & $\begin{array}{c}273 \\
(98.9 \%)\end{array}$ & $\begin{array}{c}1 \\
(0.4 \%)\end{array}$ & $\begin{array}{c}1 \\
(0.4 \%)\end{array}$ & $\begin{array}{c}0 \\
(0.0 \%)\end{array}$ & $\begin{array}{c}0 \\
(0.0 \%)\end{array}$ & $\begin{array}{c}0 \\
(0.0 \%)\end{array}$ & $\begin{array}{c}1 \\
(0.4 \%)\end{array}$ & $\begin{array}{c}0 \\
(0.0 \%)\end{array}$ & $\begin{array}{c}0 \\
(0.0 \%)\end{array}$ & 276 \\
\hline Heterosexual & $\begin{array}{c}96 \\
(53.6 \%)\end{array}$ & $\begin{array}{c}26 \\
(14.5 \%)\end{array}$ & $\begin{array}{c}15 \\
(8.4 \%)\end{array}$ & $\begin{array}{c}2 \\
(1.1 \%)\end{array}$ & $\begin{array}{c}2 \\
(1.1 \%)\end{array}$ & $\begin{array}{c}8 \\
(4.5 \%)\end{array}$ & $\begin{array}{c}17 \\
(9.5 \%)\end{array}$ & $\begin{array}{c}11 \\
(6.1 \%)\end{array}$ & $\begin{array}{c}2 \\
(1.1 \%)\end{array}$ & 179 \\
\hline Injecting drug users & $\begin{array}{c}17 \\
(48.6 \%)\end{array}$ & $\begin{array}{c}11 \\
(31.4 \%)\end{array}$ & $\begin{array}{c}0 \\
(0.0 \%)\end{array}$ & $\begin{array}{c}0 \\
(0.0 \%)\end{array}$ & $\begin{array}{c}0 \\
(0.0 \%)\end{array}$ & $\begin{array}{c}0 \\
(0.0 \%)\end{array}$ & $\begin{array}{c}7 \\
(20.0 \%) \\
\end{array}$ & $\begin{array}{c}0 \\
(0.0 \%)\end{array}$ & $\begin{array}{c}0 \\
(0.0 \%)\end{array}$ & 35 \\
\hline Blood recipients & $\begin{array}{c}8 \\
(80.0 \%) \\
\end{array}$ & $\begin{array}{c}0 \\
(0.0 \%) \\
\end{array}$ & $\begin{array}{c}0 \\
(0.0 \%) \\
\end{array}$ & $\begin{array}{c}0 \\
(0.0 \%)\end{array}$ & $\begin{array}{c}2 \\
(20.0 \%) \\
\end{array}$ & $\begin{array}{c}0 \\
(0.0 \%) \\
\end{array}$ & $\begin{array}{c}0 \\
(0.0 \%) \\
\end{array}$ & $\begin{array}{c}0 \\
(0.0 \%) \\
\end{array}$ & $\begin{array}{c}0 \\
(0.0 \%) \\
\end{array}$ & 10 \\
\hline Mother-to-child & $\begin{array}{c}0 \\
(0.0 \%)\end{array}$ & $\begin{array}{c}1 \\
(50.0 \%)\end{array}$ & $\begin{array}{c}1 \\
(50.0 \%)\end{array}$ & $\begin{array}{c}0 \\
(0.0 \%)\end{array}$ & $\begin{array}{c}0 \\
(0.0 \%)\end{array}$ & $\begin{array}{c}0 \\
(0.0 \%)\end{array}$ & $\begin{array}{c}0 \\
(0.0 \%)\end{array}$ & $\begin{array}{c}0 \\
(0.0 \%)\end{array}$ & $\begin{array}{c}0 \\
(0.0 \%)\end{array}$ & 2 \\
\hline Unknown & $\begin{array}{c}15 \\
(46.9 \%)\end{array}$ & $\begin{array}{c}8 \\
(25.0 \%)\end{array}$ & $\begin{array}{c}2 \\
(6.3 \%)\end{array}$ & $\begin{array}{c}0 \\
(0.0 \%)\end{array}$ & $\begin{array}{c}0 \\
(0.0 \%)\end{array}$ & $\begin{array}{c}0 \\
(0.0 \%)\end{array}$ & $\begin{array}{c}6 \\
(18.8 \%)\end{array}$ & $\begin{array}{c}1 \\
(3.1 \%)\end{array}$ & $\begin{array}{c}0 \\
(0.0 \%)\end{array}$ & 32 \\
\hline Total & $\begin{array}{c}409 \\
(76.6 \%)\end{array}$ & $\begin{array}{c}47 \\
(8.8 \%)\end{array}$ & $\begin{array}{c}19 \\
(3.6 \%)\end{array}$ & $\begin{array}{c}2 \\
(0.4 \%)\end{array}$ & $\begin{array}{c}4 \\
(0.7 \%)\end{array}$ & $\begin{array}{c}8 \\
(1.5 \%)\end{array}$ & $\begin{array}{c}31 \\
(5.8 \%)\end{array}$ & $\begin{array}{c}12 \\
(2.2 \%)\end{array}$ & $\begin{array}{c}2 \\
(0.4 \%)\end{array}$ & 534 \\
\hline
\end{tabular}

\section{DISCUSSION}

The Czech Republic (CR) ranks among low level HIV/AIDS epidemic European countries with cumulative incidence of 89 cases per 1 million population $(4 ; 8)$. The laboratory diagnosis of HIV was implemented in the country late in 1985 when the first HIV/AIDS cases were detected among homosexuals (MSMs), blood donors and blood transfusion recipients $(9 ; 10)$. It was suggested that HIV infection invaded CR via MSMs and blood products of Czech as well as foreign origin. MSMs were a target population for commercial sex with Western European customers. The virus isolates from that time, all classified into HIV-1 subtype B, support the theory that HIV infection was imported to the country from Western Europe.

Regarding the genetic characteristics of HIV isolates, the situation changed after 1989 when the frontiers of the Czech Republic opened to the western and eastern world. A new trend could be traced in the HIV spread in CR: since 1991, with subtype $B$ remaining the predominant HIV clade as in the previous period, other subtypes have emerged $(11 ; 12)$. Not surprisingly, the times of great East - West migration influenced the spread of HIV-1 subtypes unknown until now in the Central Europe including CR $(13 ; 14)$. Subtypes prevalent in the recent epidemic outbreak of HIV infection in Eastern Europe (especially in Russia, Ukraine, Belarus, Baltic States) were identified in CR.

Subtype F1 known as the causative agent of a big HIV/AIDS epidemic in children in Romania (15) was introduced to CR by second generation Czech emigrants repatriated to the country of their ancestors. No further spread of this subtype was observed in CR.

Genetic and molecular epidemiology analyses of HIV-1 isolates from a given region carried out on a long-term basis can be helpful in tracing the course of the HIV/AIDS epidemic. Selection of HIV epitopes suitable for effective HIV vaccine construction may be another outcome of such studies.

\section{Acknowledgements}

This study was supported by grant No. NR 7843-3 of the Internal Grant Agency of the Ministry of Health of the Czech Republic (IGA).

\section{REFERENCES}

1. Anastassopoulou CG, Kostrikis LG. Global genetic variation of HIV-1 infection. Curr HIV Res. 2006 Jul;4(3):365-73.

2. Bobkov AF, Kazennova EV, Selimova LM, Khanina TA, Ryabov GS, Bobkova MR, et al. Temporal trends in the HIV-1 epidemic in Russia: predominance of subtype A. J Med Virol. 2004 Oct;74(2):191-6.

3. Lazouskaya NV, Eremin VF, Adema KW, Gasich EL, Baan E, Lukashov VV. The HIV type 1 epidemic in Belarus: predominance of Eastern European subtype A strains and circulation of subtype B viruses. AIDS Res Hum Retroviruses. 2005 Sep;21(9):830-3.

4. EuroHIV. HIV/AIDS Surveillance in Europe. End-year report 2005. No.73. Saint-Maurice: French Institute for Public Health Service; 2006.

5. Saad MD, Shcherbinskaya AM, Nadai Y, Kruglov YV, Antonenko SV, Lyullchuk MG, et al. Molecular epidemiology of HIV Type 1 in Ukraine: birthplace of an epidemic. AIDS Res Hum Retroviruses. 2006 Aug;22(8):709-14.

6. De Oliveira T, Deforche K, Cassol S, Salminem M, Paraskevis D, Seebregts C, et al. An automated genotyping system for analysis of HIV-1 and other microbial sequences. Bioinformatics. 2005 Oct 1;21(19):3797-800.

7. Haberman SJ. The analysis of residuals in cross-classified tables. Biometrics. 1973;29(1):205-20.

8. Brůčková M, Malý M, Vandasová J.HIV/AIDS incidence and spread in the Czech Republic in 2006. Zpr Cent Epid Mikrobiol. 2007;16(1):36-40. (In Czech.)

9. Brůčková M. 25 years of AIDS. Zpr Cent Epid Mikrobiol. 2006;15(12):50304. (In Czech.)

10. Hamers FF, Devaux I, Alix J, Nardone A. HIV/AIDS in Europe: trends and EU-wide priorities. Euro Surveill. 2006 Nov 23;11(11):E061123.1.

11. Quinones-Mateu ME, Albright JL, Torre V, Reiniš M, Vandasová J, Brůčková M, et al. Molecular epidemiology of HIV type 1 isolates from the Czech Republic: identification of an env E subtype case. AIDS Res Hum Retroviruses. 1999 Jan 1;15(1):85-9.

12. Reiniš M, Bručková M, Graham RR, Vandasová J, Staňková M, Carr JK. Genetic subtypes of HIV type 1 viruses circulating in the Czech Republic. AIDS Res Hum Retroviruses. 2001 Sep 1;17(13):1305-10.

13. Stanojevic M, Papa A, Papadimitriou E, Zerjav S, Jevtovic D, Salemovic D, et al. HIV-1 subtypes in Yugoslavia. AIDS Res Hum Retroviruses. 2002 May 1;18(7):519-22.

14. Babic DZ, Poljak M, Seme K, Tomazic J, Vidmar L. Molecular epidemiology of HIV-1 subtypes based on analysis of pol sequences in Slovenia 1996-2005. J Med Virol. 2006 Aug;78(8):997-1002.

15. Apetrei C, Necula A, Holm-Hansen C, Loussert-Ajaka I, Pandrea I, Cozmei C, et al. HIV-1 diversity in Romania. AIDS. 1998 Jun 18;12(9):1079-85.

Received May 22, 2008 Accepted June 11, 2008 